\title{
VOLATILITY SPILLOVER PADA PASAR SAHAM INDONESIA, CINA, DAN INDIA
}

\author{
$\operatorname{Martin}^{1}$; Yunita ${ }^{2}$ \\ 1, 2 Jurusan Akuntansi, Fakultas Ekonomi dan Bisnis, Universitas Bina Nusantara \\ Jln. K.H. Syahdan No. 9, Palmerah, Jakarta Barat 11480
}

\begin{abstract}
Globalization and advanced information technology easing us for obtaining information from global stock markets. With that condition, volatility in domestic capital market could be affected by volatility from global stock markets. The effect would have greater impact if the capital markets are located in same region. That concern will be answered in this research, about volatility spillover in Indonesia, China, and India capital market. This research using daily return data from each country indices from January 1, 2006 until April 20, 2010 applying econometric model GARCH $(1,1)$. The result showing us that there is bidirectional volatility spillover between Indonesia and India. Meanwhile, there is only single way volatility spillover between Indonesia and China.
\end{abstract}

Keywords: volatility, volatility spillover, GARCH

\begin{abstract}
ABSTRAK
Seiring dengan perkembangan teknologi informasi dan globalisasi semakin memudahkan kita untuk memperoleh informasi dari pasar saham negara lain. Dengan demikian, volatilitas yang terjadi di dalam pasar saham domestik bisa saja dipengaruhi oleh pasar saham negara lain. Pengaruh tersebut lebih besar kemungkinannya untuk terjadi apabila antar pasar saham terletak pada wilayah regional yang sama. Hal tersebut akan diteliti dalam penelitian ini, yakni mengenai volatility spillover pada pasar saham Indonesia, Cina, dan India. Penelitian ini menggunakan data imbal hasil harian dari indeks masing-masing negara dari 1 Januari 2006 hingga 20 April 2010 dengan menggunakan model ekonometrik GARCH $(1,1)$. Hasil penelitian menunjukkan adanya volatility spillover dua arah antara Indonesia dengan India. Sementara itu, volatility spillover antara Indonesia dan Cina sifatnya hanyalah searah.
\end{abstract}

Kata kunci: volatility, volatility splillover, GARCH 


\section{PENDAHULUAN}

Investasi pada pasar saham merupakan salah satu alternatif bagi investor untuk melakukan investasi. Seiring dengan globalisasi dan kemajuan dalam perkembangan teknologi informasi, pada saat ini investor dapat menanamkan investasinya baik pada pasar saham domestik maupun pada pasar saham negara lain. Fakta menunjukkan bahwa kejatuhan pasar saham Amerika Serikat yang diakibatkan oleh subprime mortgage serta merta diikuti oleh kejatuhan pasar saham di negara lainnya. Fakta lainnya yang dapat ditangkap dari keadaan di lapangan di antaranya adalah apabila pasar saham Amerika Serikat ditutup menguat, besar kemungkinan pasar saham negara lainnya akan turut menguat juga dan demikian sebaliknya.

Dari gambaran di atas, dapat ditarik kesimpulan sementara bahwa kejadian yang terjadi di pasar saham Amerika Serikat mempengaruhi kepada pasar saham negara lainnya. Dengan kata lain, terdapat korelasi yang cukup tinggi antara pasar saham Amerika Serikat dengan pasar saham negara lainnya. Selain itu, sempat disuspensinya Bursa Efek Indonesia (BEI) pada 8 Oktober 2008 akibat menurunnya IHSG lebih dari $10 \%$ yang dikatakan diakibatkan oleh investor panik dan tidak berperilaku secara rasional dikarenakan krisis finansial yang terjadi di Amerika Serikat juga menarik untuk diteliti dan dibuktikan bahwa apakah memang benar terdapat pengaruh antara kedua pasar saham tersebut atau kejadian tersebut dipengaruhi oleh hal lain yang terjadi di dalam negeri, bukan disebabkan oleh kejadian yang terjadi di luar negeri.

Pada tahun 2008, IHSG memberikan imbal hasil sebesar -50,64\%. Apabila dibandingkan dengan tahun 2006 dan 2007, IHSG memberikan imbal hasil secara berturut-turut sebesar 55,10\% dan $52,10 \%$. Adapun puncak IHSG sebelum terjadi krisis finansial dicapai pada minggu kedua pada Januari 2008, yakni mencapai 2.830,26 dan pada intrahari sempat mencapai 2.838,48. Seiring dengan krisis finansial yang dipicu oleh krisis subprime mortgage di Amerika Serikat, IHSG terus mengalami penurunan. Pada akhir Oktober 2008 IHSG menyentuh level 1.111,39. Sementara itu, pada akhir tahun 2008 IHSG ditutup pada level 1.355,41.

Namun demikian, memasuki akhir tahun 2009 pasar saham berangsur pulih. Dan yang menariknya adalah pemulihan pasar saham tercepat dicapai oleh pasar saham negara berkembang. Negara BRIC (Brasil, Rusia, India, dan Cina) yang digadang-gadang sebagai poros ekonomi dunia baru juga menunjukkan pemulihan lebih cepat dibanding pasar saham Amerika. Tidak dapat dilupakan pula pandangan beberapa peneliti yang menganggap Indonesia merupakan salah satu negara yang dapat menjadi kekuatan ekonomi dunia di masa mendatang yang akan bergabung dengan negara BRIC dan menjadikan BRIIC (Brasil, Rusia, India, Indonesia, dan Cina). Pandangan tersebut mungkin dapat dijustifikasi sebagai kebenaran apabila menggunakan pasar saham sebagai realita.

Dengan kondisi fundamental ekonomi yang relatif cukup baik, pasar saham Indonesia berhasil menorehkan sejarah baru. Di tengah indeks pasar saham negara maju masih terengah-engah untuk mencapai level sebelum krisis, justru Indeks Harga Saham Gabungan (IHSG) berhasil melewati level tertinggi yang pernah dicapai sebelum krisis. Posisi IHSG tertinggi untuk intrahari pada saat ini berada pada level 2.913,72. Sementara harga penutupan tertinggi berada pada level 2.900,53. Hingga periode April, pasar saham Indonesia memberikan imbal hasil yang paling besar selama tahun 2010 dibandingkan dengan seluruh pasar saham di dunia.

Banyak penelitian yang telah meneliti mengenai pergerakan volatilitas pasar saham ini. Namun, pada umumnya kebanyakan penelitian dilakukan terhadap volatilitas pada pasar saham negara maju. Sementara itu, belum ada penelitian yang dilakukan untuk meneliti volatility spillover antara pasar saham negara berkembang. Menarik untuk diteliti apakah terdapat volatility spillover di antara pasar saham negara berkembang yang kebetulan juga terletak pada satu wilayah/benua yang sama ini 
(Indonesia, Cina, dan India). Hal tersebut dikarenakan adanya karakteristik yang sama, seperti samasama mengalami kejatuhan terimbas krisis finansial Amerika Serikat serta relatif lebih cepat pulih dibandingkan pasar saham Amerika Serikat. Berikut ini disajikan data varians imbal hasil harian pasar saham Indonesia, Amerika Serikat, dan Jepang yang dapat dijadikan sebagai salah satu ukuran volatilitas. Adapun varians ini diukur berdasarkan imbal hasil aritmatika dari IHSG (Indonesia), SSE Composite Index (Cina), dan BSE Sensex.

Dapat dilihat pada Gambar 1, bahwa varians dari pasar saham Indonesia merupakan yang terendah dibandingkan dengan pasar saham Cina dan India untuk periode 2006 hingga 2009. Sementara itu, untuk periode 2010 (hingga 20 April) varians pasar saham Indonesia merupakan yang kedua setelah pasar saham Cina.

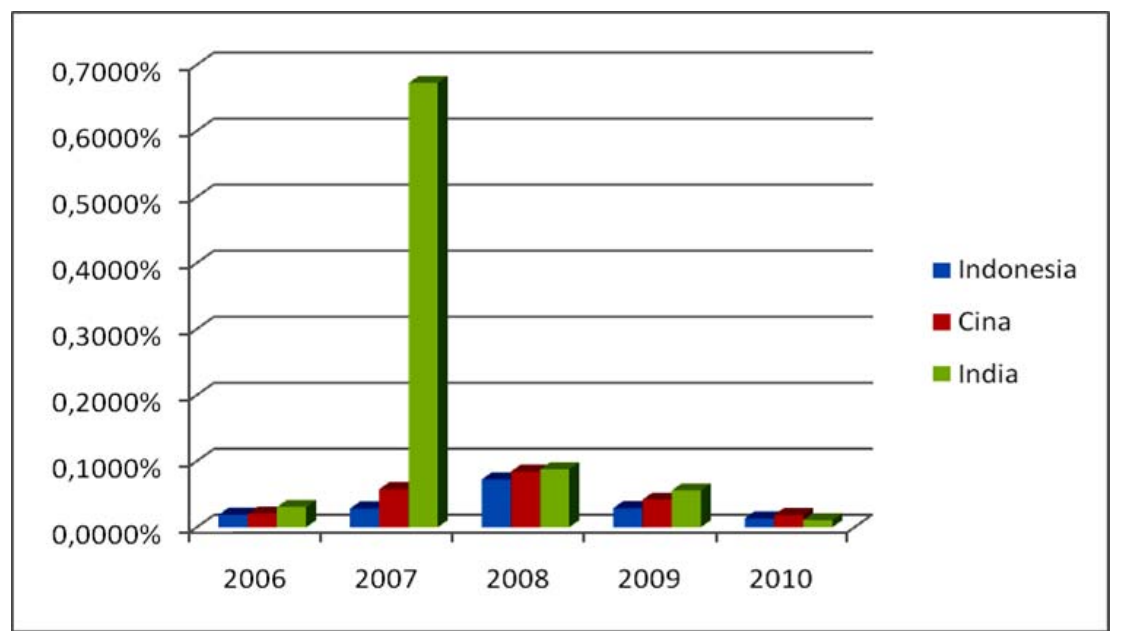

Gambar 1 Varians Imbal Hasil Pasar Saham Harian Indonesia, Amerika Serikat, dan Jepang.

Penelitian yang dilakukan oleh Balasubramanyan dan Premaratne (2003) menunjukkan bahwa dengan menggunakan $V A R$, hasil dari dekomposisi varians pasar saham Hong Kong mempengaruhi sebesar 22\% terhadap ramalan varians error pasar saham Singapura. Pengaruh ini jauh lebih besar apabila dibandingkan dengan pengaruh yang ditimbulkan dari pasar saham Amerika Serikat dan Inggris. Sementara itu, Mukherjee dan Mishra (2008) melakukan penelitian pada pasar saham India dan 12 pasar saham Asia lainnya. Hasil penelitian mereka menyimpulkan bahwa beberapa pasar saham Asia (diantaranya adalah pasar saham Hong Kong, Indonesia, dan Singapura) mempengaruhi volatilitas di pasar saham India. Sementara itu, volatility spillover pasar saham India hanyalah kepada pasar saham Pakistan dan Sri Lanka.

Penelitian volatilitas pada pasar saham Indonesia dengan beberapa pasar saham negara berkembang di wilayah regional yang sama penting dilakukan, dengan tujuan untuk mengetahui bahwa seberapa besar pergerakan pasar saham negara lain dapat mempengaruhi pergerakan saham di Indonesia. Selain itu juga dapat diteliti apakah kejadian yang terjadi pada pasar saham Indonesia dapat mempengaruhi kepada pasar saham negara lainnya. Penelitian yang dilakukan kali ini adalah untuk menguji contemporaneous volatility spillover (langsung terjadi pada hari yang sama). Hal ini disebabkan waktu perdagangan di pasar saham Indonesia, Cina, dan India terjadi pada waktu yang relatif sama. 


\section{Landasan Teori}

\section{Globalisasi dan Kaitannya dengan Pasar Saham}

Semakin meningkatnya aktivitas ekonomi antar-regional dan liberalisasi pasar keuangan sejak akhir 1980-an menghasilkan integrasi ekonomi regional di seluruh dunia. Globalisasi ini juga memungkinkan perusahaan yang terletak di sebuah negara menjual sahamnya di negara lain sebagai sumber baru meningkatkan modal untuk membiayai ekspansinya tersebut. Perluasan pasar ini menggambarkan perkembangan terkini dalam teknologi komunikasi. Dengan begitu pesatnya perkembangan teknologi komunikasi dan informasi membuat perluasan pasar finansial yang tadinya hanya berskala lokal dapat menjadi skala internasional.

Dengan kondisi di atas, yakni berkembangnya globalisasi dan juga perluasan pasar finansial mengakibatkan semakin berkembangnya integrasi pasar finansial. Semakin berkembangnya integrasi pasar finansial pada umumnya, dan pasar saham pada khususnya mengakibatkan imbal hasil dan juga volatilitas antar pasar saham dapat saling terkait. Hal itu terjadi karena globalisasi berkaitan dengan perdagangan (trading) dan juga investasi, sehingga berita mengenai fundamental ekonomi pada sebuah negara hampir dipastikan memiliki dampak bagi negara lainnya. Alasan lain dari terjadinya korelasi perubahan harga saham antara negara satu dan negara lainnya adalah market contagion, yakni perubahan harga saham di suatu negara diakibatkan oleh perubahan di negara lainnya yang bukan disebabkan oleh fundamental ekonomi negara tersebut. Contoh dari market contagion ini adalah kejatuhan pasar saham Amerika Serikat (New York) pada bulan Oktober tahun 1987 yang dikenal dengan Black Monday mengakibatkan penurunan harga saham dunia.

\section{Volatilitas}

Globalisasi dan aliran modal multi-direksional antara pasar finansial semakin meningkatkan interdependensi pasar. Banyak studi empiris yang membuktikan co-movements dan interdependensi antara pasar saham di berbagai negara. Terdapat dua pendekatan utama yang digunakan untuk menyelidiki hal tersebut. Pendekatan pertama adalah meneliti berbagai aspek interdependensi pasar menggunakan cointegration dan causality. Salah satu penelitian yang menggunakan pendekatan pertama ini ialah penelitian yang dilakukan oleh Eun dan Shim (1989). Pendekatan kedua adalah meneliti interdependensi dalam kaitannya dengan volatility spillover. Salah satu penelitian yang menggunakan pendekatan kedua ini ialah penelitian yang dilakukan oleh Hamao, Masulis, dan Ng (1990).

Menurut King dan Wadhwani (1990), seorang investor dalam pasar saham menggunakan pengumuman atau informasi yang terakumulasi dari penutupan terakhir pasar saham domestik untuk mengestimasi dampaknya terhadap harga pembukaan pada pasar saham. Atau, ia dapat menggunakan perubahan harga dari pasar saham negara lainnya yang telah dibuka lebih awal dibandingkan pasar saham domestik untuk mengestimasi kemungkinan dampaknya terhadap pasar saham domestik. Menurut Calvet, Fischer, dan Thompson (2004), tujuan utama dalam meneliti volatility spillover adalah untuk memahami bagaimana gabungan pergerakan volatilitas dalam mempengaruhi distribusi tingkat imbal hasil portofolio. Distribusi tingkat imbal hasil portofolio memiliki implikasi terhadap manajemen risiko harian, seleksi portofolio, dan penentuan harga derivatif. Pergerakan gabungan dari volatilitas membantu dalam memahami transmisi shock dalam sistem finansial global, namun demikian terdapat efek yang mempengaruhi volatilitas dari pasar finansial dan aset-aset mereka, yakni volatility spillover.

Menurut Rigobon dan Sack (2003), harga-harga aset saling berkaitan satu sama lain. Menganalisa dalam sebuah pasar tunggal sendiri tanpa memperhatikan aspek lainnya berarti mengabaikan informasi penting tentang perilaku pasar tersebut. Perubahan harga sebuah aset pada 
pasarnya tidak hanya dipengaruhi oleh volatility shock, tetapi juga dipengaruhi oleh reaksinya terhadap shock pada harga aset di pasar yang berbeda.

\section{Penelitian Terdahulu}

Beberapa penelitian terdahulu telah pernah dilakukan yang menunjukkan adanya gejala volatility spillover ini. Eun dan Shim (1989) menganalisa imbal hasil harian pada pasar saham di Australia, Hong Kong, Jepang, Prancis, Kanada, Swiss, Jerman, Amerika Serikat, dan Inggris. Mereka menemukan adanya interdependensi yang substansial antara masing-masing pasar saham dengan Amerika Serikat menjadi pasar yang paling berpengaruh. Terhadap inovasi yang terjadi di Amerika Serikat, seluruh pasar Eropa dan Asia Pasifik merespon dengan kuat dengan lag satu hari. Kebanyakan respon terhadap shock selesai dalam dua hari.

Hamao, Masulis, dan Ng (1990) menggunakan data harga saham harian dan intra-harian pada pasar saham Jepang (indeks Nikkei 225), Inggris (indeks FTSE), dan Amerika Serikat (indeks S\&P 500) selama tiga tahun (dari 1 April 1985 hingga 31 Maret 1988). Mereka melakukan penelitian mengenai interdependensi harga dan volatilitas harga diantara ketiga pasar saham tersebut. Dalam melakukan penelitian tersebut, perhitungan imbal hasil dilakukan dengan membandingkan harga penutupan dengan harga pembukaan, dan harga pembukaan dengan harga penutupan. Penelitian tersebut menggunakan model GARCH-M (1,1). Hasil penelitian tersebut menyimpulkan bahwa terdapat efek spillover yang signifikan dari pasar saham Amerika Serikat dan Inggris kepada pasar saham Jepang, namun tidak sebaliknya.

Park dan Fatemi (1993) meneliti hubungan antara pasar saham negara-negara wilayah Basin Pasifik dengan Amerika Serikat, Inggris, dan Jepang. Pasar Amerika Serikat merupakan yang paling berpengaruh dibandingkan dengan Inggris, dan Jepang. Dalam penelitian tersebut ditemukan bahwa Australia merupakan yang paling sensitif terhadap pasar Amerika Serikat. Singapura, Hong Kong, dan Selandia Baru masuk ke dalam kelompok berikutnya yang menunjukkan hubungan tingkat menengah terhadap pasar-pasar tersebut. Sementara itu, Korea, Taiwan, dan Thailand menunjukkan adanya hubungan yang kecil terhadap pasar-pasar tersebut. Ekonomi Basin Pasifik mempunyai struktur unik yang berbeda dengan negara-negara yang memiliki pasar berkembang dan pergerakan sahamnya dipengaruhi oleh faktor domestik.

Lin, Engle, dan Ito (1994) melakukan penelitian yang menyelidiki bagaimana imbal hasil dan volatilitas dari indeks saham saling berkorelasi antara pasar saham Jepang dan Amerika Serikat. Data yang digunakan adalah data intraharian dari indeks Nikkei 225 dan indeks $S \& P$ 500. Dari data tersebut dapat dihitung daytime return (perbandingan antara harga pembukaan dengan harga penutupan), serta overnight return (perbandingan antara harga penutupan sebelumnya dengan harga pembukaan). Penelitian yang menggunakan model GARCH-M yang juga digunakan oleh Hamao, Masulis, dan Ng (1990) menemukan bahwa daytime return dari luar negeri dapat mempengaruhi overnight return domestik secara signifikan. Seringkali disebutkan bahwa pasar saham Amerika Serikat mempengaruhi pasar saham Jepang namun tidak sebaliknya. Akan tetapi, dalam penelitian yang dilakukan oleh Lin, Engle, dan Ito tersebut ditemukan bahwa interdependensi antar pasar dalam hal imbal hasil dan volatilitas adalah bi-directional antara pasar saham Jepang dan Amerika Serikat.

Janakiramanan dan Lamba (1998) meneliti secara empiris hubungan antara pasar saham negara pada wilayah Basin Pasifik. Hasilnya menunjukkan bahwa Amerika Serikat mempengaruhi semua pasar saham, kecuali pasar saham Indonesia yang masih relatif terisolasi. Pasar-pasar yang secara geografis dan ekonomis berdekatan menunjukkan pengaruh signifikan satu sama lain. Secara keseluruhan, pengaruh pasar Amerika Serikat terhadap pasar Australia-Asia semakin berkurang pada beberapa tahun terakhir, dan pasar berkembang Indonesia menjadi semakin terintegrasi dengan pasarpasar ini. 
Indrawati (2002) menggunakan model VAR dan VEC dengan pendekatan GNC untuk mengkaji hubungan dinamis antara variabel ekonomi makro-moneter dan indeks pasar saham. Hasil penelitiannya menunjukkan bahwa pasar saham Indonesia terintegrasi dengan pasar saham Amerika Serikat. 1\% kenaikan pada pasar saham Amerika Serikat akan mempengaruhi kenaikan IHSG sebesar 0,32\%. Dari penelitian tersebut juga disimpulkan bahwa antara pasar saham Indonesia dengan pasar saham Thailand, Taiwan, dan Korea Selatan terjadi hubungan Granger cause bidirectional. Selain itu, disimpulkan juga bahwa semua pasar saham (Indonesia, Thailand, Taiwan, dan Korea Selatan) terintegrasi dengan pasar saham Amerika Serikat.

Balasubramanyan dan Premaratne (2003) melakukan penelitian dengan menggunakan data imbal hasil harian dari 1 Januari 1992 hingga 26 Agustus 2002 untuk menyelidiki volatility spillover dan comovement antara pasar saham Singapura dengan pasar saham Amerika Serikat, Inggris, Hong Kong, dan Jepang. Hasil penelitian yang menarik adalah terdapat volatility spillover yang signifikan dari pasar saham Singapura ke Hong Kong, Jepang, dan Amerika Serikat. Padahal dalam hal pengaruh dan dominasi pasar, pasar saham Hong Kong, Jepang, dan Amerika Serikat jauh lebih berpengaruh dan dominan dibandingkan dengan pasar saham Singapura. Kebanyakan penelitian yang dilakukan mengarah kepada kesimpulan bahwa efek spillover akan signifikan dari pasar yang dominan kepada pasar yang lebih kecil, dan hanya searah. Hal ini menjadi menarik melihat dari hasil penelitian Balasubramanyan dan Premaratne ini ditemukan bahwa adanya volatility spillover yang kecil, namun signifikan, dari pasar saham Singapura ke pasar saham Hong Kong, Jepang, dan Amerika Serikat.

Mukherjee dan Mishra (2008) melakukan penelitian mengenai volatility spillover terhadap pasar saham India dengan 12 pasar saham Asia lainnya (yakni: Cina, Hong Kong, Indonesia, Jepang, Korea, Malaysia, Pakistan, Filipina, Singapura, Sri Lanka, Taiwan, dan Thailand) dengan menggunakan data dari Juli 1997 hingga April 2008. Secara garis besar, Mukherjee dan Mishra membagi penelitiannya menjadi dua bagian besar yakni melakukan penelitian spillover dengan menggunakan data intraday (perbandingan harga pembukaan dengan harga penutupan), dan overnight (perbandingan harga penutupan dengan harga pembukaan). Penelitian mereka menggunakan model GARCH $(1,1)$.

Hasil penelitian berkaitan dengan intraday information/volatility spillover menunjukkan bahwa adanya intraday volatility spillover yang signifikan dari pasar saham Hong Kong, Indonesia, Korea, Singapura, dan Thailand yang mempengaruhi volatilitas intraday pada pasar saham India. Sementara itu, volatility spillover dari pasar saham India hanyalah kepada pasar saham Pakistan dan Sri Lanka. Dengan demikian dari uraian-uraian di atas, dapat disusun hipotesis sebagai berikut: Hipotesis satu : Terdapat volatility spillover antara pasar saham Indonesia, Cina, dan India. Hipotesis dua : Terjadi volatility spillover dua arah antara pasar saham Indonesia, Cina, dan India.

\section{METODE PENELITIAN}

\section{Jenis dan Pengumpulan Data}

Data yang digunakan adalah data harga penutupan indeks. Data imbal hasil harian $y_{t}$ dihitung dengan menggunakan rumusan imbal hasil aritmatika sebagai berikut:

$$
R_{t}=\left(P_{t}-P_{t-1}\right) / P_{t-1}
$$

Data harga diperoleh melalui Yahoo! Finance untuk periode dari 1 Januari 2006 hingga 20 April 2010. Digunakannya data harian dikarenakan imbal hasil harian dapat menangkap semua interaksi yang memungkinkan. Sementara itu, apabila digunakan data mingguan atau bulanan dapat 
menghilangkan interaksi yang mungkin hanya berlangsung selama beberapa hari. Adapun data yang digunakan adalah indeks dari masing-masing negara, untuk pasar saham Indonesia digunakan data Indeks Harga Saham Gabungan (IHSG), data pasar saham Cina menggunakan Shanghai Stock Exchange Composite Index, dan data pasar saham India menggunakan Bombay Stock Exchange Sensitive Index.

\section{Model Ekonometri yang Digunakan}

Dengan tujuan untuk memperoleh informasi mengenai volatility spillover dari data time series, maka dalam penelitian ini akan menggunakan model $G A R C H(1,1)$ yang dikembangkan oleh Bollerslev (1986) dan Taylor (1986). Model berikut diestimasi menggunakan Maximum Likelihood Procedure dengan menerapkan algoritma Berndt-Hall-Hall-Hausman (BHHH). Berikut ini adalah model yang akan digunakan untuk menguji contemporaneous volatility spillover:

$$
\begin{aligned}
& R_{i, t}=\gamma_{0}+\gamma_{1} R_{i, t-1}+\gamma_{2} R_{j, t}+\gamma_{3} h_{j, t}+\varepsilon_{i, t} \\
& h_{i, t}=\alpha_{0}+\alpha_{1} \varepsilon_{i, t-1}^{2}+\alpha_{2} h_{i, t-1}+\delta_{1} h_{j, t} \\
& R_{j, t}=\theta_{0}+\theta_{1} R_{j, t-1}+\theta_{2} R_{i, t}+\theta_{3} h_{i, t}+\varepsilon_{j, t} \\
& h_{j, t}=\beta_{0}+\beta_{1} \varepsilon_{j, t-1}^{2}+\beta_{2} h_{j, t-1}+\varphi_{1} h_{i, t}
\end{aligned}
$$

Di mana:

$R_{i, t} \quad=$ imbal hasil pasar saham domestik pada periode $\mathrm{t}$,

$R_{i, t-1}=$ imbal hasil pasar saham domestik pada periode $\mathrm{t}-1$,

$R_{j, t} \quad=$ imbal hasil pasar saham negara asing pada periode $\mathrm{t}$,

$h_{i, t}=$ volatilitas pasar saham domestik pada periode $\mathrm{t}$,

$h_{i, t-1}=$ volatilitas pasar saham domestik pada periode $\mathrm{t}-1$,

$h_{j, t}=$ volatilitas pasar saham negara asing pada periode $\mathrm{t}$,

$\varepsilon_{i, t}=$ error dari pasar saham domestik pada periode $\mathrm{t}$,

$\varepsilon_{j, t} \quad=$ error dari pasar saham negara asing pada periode $\mathrm{t}$.

Dari model di atas dapat dilihat bahwa $R_{j, t}$ dan $h_{j, t}$ adalah variabel contemporaneous spillover dari pasar saham asing (negara lain).

Penelitian hanya dilakukan dengan menguji contemporaneous volatility spillover karena waktu perdagangan yang relatif sama antara ketiga pasar saham, sehingga bisa dikatakan tidak ada (atau relatif sedikit) lagging time antara pasar saham Indonesia, Cina, dan India.

\section{HASIL DAN PEMBAHASAN}

\section{Pengujian volatility spillover antara Indonesia dengan Cina}

Pada bagian ini akan dibahas mengenai pengujian volatility spillover antara Indonesia dengan Cina. Dari tabel 1 dapat kita lihat bahwa koefisien $\delta_{1}$ yang menunjukkan adanya volatility spillover dari Cina. Volatilitas pada pasar saham Indonesia dipengaruhi oleh volatility spillover dari pasar 
saham Cina pada tingkat kepercayaan 95\%. Sementara itu, dari tabel 2 dapat kita ketahui bahwa ternyata volatilitas pasar saham Cina tidak dipengaruhi oleh volatility spillover dari pasar saham Indonesia. Dari pengujian model pertama ini, maka dapat ditarik kesimpulan bahwa terjadi volatility spillover antara pasar saham Indonesia dengan Cina. Adapun volatility spillover tersebut sifatnya hanyalah searah (Cina mempengaruhi Indonesia), namun ternyata pasar saham Indonesia tidak mempengaruhi pasar saham Cina. Kemungkinan tidak terjadinya volatility spillover dari pasar saham Indonesia ke pasar saham Cina adalah dikarenakan investor yang dapat masuk ke pasar saham Cina hanyalah investor lokal, sehingga mungkin mereka cenderung mengabaikan informasi dari luar. Sementara itu, banyak investor asing di pasar saham Indonesia yang biasanya mengambil keputusan berdasarkan informasi yang mereka terima baik itu dari pergerakan/volatilitas pasar saham Amerika Serikat, pasar saham Eropa, dan bahkan pasar saham kawasan regional yang sama.

Tabel 1 Hasil Pengolahan Data dari Persamaan (1) dan (2), Indonesia dan Cina

\begin{tabular}{cccccccc}
\hline$\gamma_{0}$ & $\gamma_{1}$ & $\gamma_{2}$ & $\gamma_{3}$ & $\alpha_{0}$ & $\alpha_{1}$ & $\alpha_{2}$ & $\delta_{1}$ \\
\hline $0,0028^{*}$ & $0,0625^{* *}$ & $0,1917^{*}$ & $-3,1027$ & $0,0000^{* *}$ & $0,1459^{*}$ & $0,8218^{*}$ & $0,0153^{* *}$ \\
$(3,1089)$ & $(1,8015)$ & $(10,0583)$ & $(-1,6203)$ & 2,1575 & 9,1442 & 47,0871 & 2,1060 \\
\hline
\end{tabular}

Sumber: Hasil pengolahan data dengan menggunakan EViews.

Catatan: * Signifikan dalam 1\%, ** Signifikan dalam 5\%, *** Signifikan dalam 10\%. Angka dalam kurung merupakan z-Statistic.

Tabel 2 Hasil Pengolahan Data dari Persamaan (3) dan (4), Indonesia dan Cina

\begin{tabular}{cccccccc}
\hline$\theta_{0}$ & $\theta_{1}$ & $\theta_{2}$ & $\theta_{3}$ & $\beta_{0}$ & $\beta_{1}$ & $\beta_{2}$ & $\varphi_{1}$ \\
\hline $0,0015^{* *}$ & 0,0069 & $0,3341^{*}$ & $-0,9575$ & $0,0000 *$ & $0,0839 *$ & $0,9047 *$ & 0,0013 \\
$(1,9737)$ & $(0,2094)$ & 10,3115 & $-0,5510$ & 3,1466 & 7,5277 & 77,9969 & 0,2377 \\
\hline
\end{tabular}

Sumber: Hasil pengolahan data dengan menggunakan EViews.

Catatan: * Signifikan dalam 1\%, ** Signifikan dalam 5\%, *** Signifikan dalam 10\%.

Angka dalam kurung merupakan z-Statistic.

\section{Pengujian Volatility Spillover antara Indonesia dengan India}

Berikut ini disajikan hasil pengolahan data imbal hasil antara Indonesia dan India dengan menggunakan persamaan (1) hingga (4). Dari tabel 3 di bawah ini, dapat dilihat bahwa terjadi volatility spillover dari pasar saham India kepada pasar saham Indonesia yang signifikan dalam $1 \%$. Volatilitas pasar saham Indonesia juga dipengaruhi oleh volatility spillover dari pasar saham India.

Tabel 3 Hasil Pengolahan Data dari Persamaan (1) dan (2), Indonesia dan India

\begin{tabular}{cccccccc}
\hline$\gamma_{0}$ & $\gamma_{1}$ & $\gamma_{2}$ & $\gamma_{3}$ & $\alpha_{0}$ & $\alpha_{1}$ & $\alpha_{2}$ & $\delta_{1}$ \\
\hline $0,0013^{* *}$ & $0,0962^{* *}$ & $0,2811^{*}$ & $-0,0351$ & $0,0000^{*}$ & $0,3683^{*}$ & $0,2601 *$ & $0,0709 *$ \\
$(2,5390)$ & $(2,3703)$ & $(50,9340)$ & $(-0,1349)$ & $(6,7512)$ & $(9,6428)$ & $(6,4228)$ & $(8,9579)$ \\
\hline
\end{tabular}

Sumber: Hasil pengolahan data dengan menggunakan EViews. 
Catatan: * Signifikan dalam 1\%, ** Signifikan dalam 5\%, *** Signifikan dalam 10\%.

Angka dalam kurung merupakan z-Statistic.

Tabel 4 Hasil Pengolahan Data dari Persamaan (3) dan (4), Indonesia dan India

\begin{tabular}{cccccccc}
\hline$\theta_{0}$ & $\theta_{1}$ & $\theta_{2}$ & $\theta_{3}$ & $\beta_{0}$ & $\beta_{1}$ & $\beta_{2}$ & $\varphi_{1}$ \\
\hline$-0,0009$ & $-0,1173^{* * *}$ & 0,6120 & $-0,6564$ & $0,0005^{*}$ & $0,1976^{*}$ & $-0,0159$ & $0,4411^{*}$ \\
$(-0,4866)$ & $(-1,9300)$ & 10,1034 & $(-0,1796)$ & $(11,0921)$ & $(8,3042)$ & $(-0,4970)$ & $(2,7538)$ \\
\hline
\end{tabular}

Sumber: Hasil pengolahan data dengan menggunakan EViews.

Catatan: * Signifikan dalam 1\%, ** Signifikan dalam 5\%, *** Signifikan dalam 10\%.

Angka dalam kurung merupakan z-Statistic.

Sementara itu dari tabel 4 dapat kita lihat bahwa terjadi juga volatility spillover dari pasar saham Indonesia kepada pasar saham India pada tingkat kepercayaan 99\%. Berarti, hubungan volatility spillover antara Indonesia dan India berlangsung dua arah. Volatility spillover yang diakibatkan dari pasar saham Indonesia ke pasar saham India, maupun sebaliknya memiliki tingkat kepercayaan yang sama yakni 99\%. Namun demikian, pengaruh yang ditimbulkan ditinjau dari besaran koefisien menunjukkan bahwa pengaruh volatilitas dari pasar saham Indonesia ke pasar saham India lebih besar dibandingkan dengan pengaruh volatilitas dari pasar saham India ke pasar saham Indonesia.

\section{Volatility Spillover antara Indonesia dengan Cina dan India}

Dari penelitian di atas, dapat diketahui bahwa terjadi volatility spillover ke pasar saham Indonesia baik dari pasar saham Cina maupun India. Volatility spillover dari pasar saham Cina signifikan dalam 5\%, sedangkan dari pasar saham India signifikan dalam $1 \%$. Sedangkan, volatility spillover dari pasar saham Indonesia hanya mempengaruhi pasar saham India dengan tingkat kepercayaan 99\%. Sementara itu, pasar saham Cina tidak terpengaruh dari volatilitas pasar saham Indonesia. Hal ini bisa dipahami bahwa investor asing tidak bisa memasuki pasar saham Cina, sehingga besar kemungkinan bahwa investor lokal cenderung mengabaikan informasi dari luar. Berbeda dengan pasar saham Indonesia dan India di mana investor biasanya mengolah informasi yang diperoleh dari pasar saham seluruh dunia, termasuk pasar saham dalam wilayah regional yang sama.

\section{SIMPULAN}

Volatilitas pasar saham Indonesia dipengaruhi oleh volatilitas dari pasar saham Cina maupun India. Hal ini sejalan dengan hipotesis pertama, yakni terjadi volatility spillover antara pasar saham Indonesia, Cina, dan India. Volatility spillover dari pasar saham Cina ke pasar saham Indonesia signifikan dalam $5 \%$, sementara itu volatility spillover dari pasar saham India ke pasar saham Indonesia signifikan dalam $1 \%$. Sementara itu, pada pengujian hipotesis kedua (terjadi volatility spillover dua arah) memperoleh hasil penelitian yang berbeda. Hipotesis tersebut tidak ditolak untuk penelitian antara Indonesia dengan India. Sementara dalam penelitian antara Indonesia dengan Cina, hipotesis tersebut ditolak. Volatilitas pasar saham India juga dipengaruhi oleh volatility spillover dari pasar saham Indonesia. Volatility spillover dari Indonesia kepada India signifikan dalam 1\%. Dengan adanya volatility spillover dari Indonesia kepada India berarti spillover yang terjadi antara kedua negara adalah dua arah (saling mempengaruhi). Sedangkan volatility spillover antara Indonesia 
dengan Cina sifatnya hanyalah searah (pasar saham Cina mempengaruhi pasar saham Indonesia, namun tidak sebaliknya). Hal itu dikarenakan tidak terjadi volatility spillover dari Indonesia kepada Cina. Untuk penelitian selanjutnya, dapat dipertimbangkan untuk meneliti apakah terjadi volatility spillover antar pasar saham negara berkembang sebagaimana yang dikemukakan di awal, yakni pada negara BRIIC (Brasil, Rusia, India, Indonesia, dan Cina). Juga menarik untuk diteliti dari sisi return spillover, selain pada volatility spillover-nya.

\section{DAFTAR PUSTAKA}

Balasubramanyan, L. (2004), Do Time-Varying Covariances, Volatility Comovement and Spillover Matter?, Pennsylvania State University Paper.

Balasubramanyan, L., and G. Premaratne. (2003), Volatility Spillover and Co-movement: Some New Evidence from Singapore, National University of Singapore Working Paper.

Calvet, L.E., A.J. Fischer, and S.B. Thompson. (2006), Volatility Comovement: A Multifrequency Approach, Journal of Econometrics, 131(1-2): 179-215.

Eun, C.S., and S.Shim. (1989), International Transmission of Stock Market Movements, Journal of Financial and Quantitative Analysis, 24 (2): 241-256.

Hamao, Y.R., R.W. Masulis, and V. K. Ng. (1990), Correlations in Price Changes and Volatility Across International Stock Markets, Review of Financial Studies, 3(2): 281-307.

Indrawati, T. (2002), Hubungan Dinamis antar Variabel Ekonomi Makro-moneter dan Indeks Pasar Saham dengan Pendekatan Granger Noncausality (GNC) dalam VAR dan VEC. Dissertation, Universitas Indonesia.

Janakiramanan, S., and A. S. Lamba. (1998), An Empirical Examination of Linkages Between PacificBasin Stock Markets, Journal of International Financial Markets, 8(2): 155-173.

King, M., and S. Wadhwani. (1990), Transmission of Volatility Between Stock Markets, Review of Financial Studies, 3(1): 5-33.

Lin, W. L., R. F. Engle, and T. Ito. (1994), Do Bulls and Bears Move Across Borders? International Transmission of Stock Returns and Volatility, Review of Financial Studies, 7: 507-538.

Mukherjee, K., and R. K. Mishra. (2008), Stock Market Integration and Volatility Spillover: India and its Major Asian Counterparts, MPRA Paper 12788, University of Munich.

Park, J., and A. M. Fatemi. (1993), The Linkages Between the Equity Markets of Pacific-Basin Countries and those of U. S., U. K., and Japan: A Vector Autoregression Analysis, Global Finance Journal, 4: 49-64.

Rigobon, R., and B. Sack. (2003), Spillovers Across US Financial Markets, Finance and Economics Discussion Series 2003-13, Board of Governors of the Federal Reserve System (U.S.). 